DOI: 10.15393/j9.art.2019.6642

УДК 821.161.1.09“19”

Наталья Владимировна Михаленко

(Москва, Российская Федерачия)

rinsan-tin@rambler.ru

\title{
Библейские алдюзии в «усадебном тексте» Б. К. Зайцева (повесть «Аграфена» и роман «Дальний край»)*
}

Аннотация. Библейские темы, мотивы, обнаруживающиеся в ранних произведениях Б. К. Зайцева, исследованы литературоведами не в полной степени. Ученые (Е. Ф. Дудина, Н. А. Иванова, О. Г. Князева и др.) фрагментарно анализировали новозаветную образность повести «Аграфена» и романа «Дальний край» без соотношения ее с теми усадебными реалиями, в которых она реализуется. Это делает изучение данных произведений с точки зрения христианской проблематики актуальной задачей. В настоящей статье на материале повести и романа будет рассмотрен мотив возвращения в усадьбу как путь блудного сына в отчий дом; мотив обретения веры, раскрывающийся в возможности услышать и понять самого себя, вернувшись в родные места, находясь в гармонии с природой; мотив смирения, принятия судьбы, несения своего креста. Православная символика (образ чаши скорбей, бурного моря жизни, камня - столпа новой веры) выступает как важный знак на пути героев, помогая осознать свое предназначение. Большое значение в повести «Аграфена» имеет мотив чудесного видения, сна, воспринимаемых героиней как божественное откровение. Усадьба в данных текстах становится топосом, с которым связана духовная эволюция героев.

Ключевые слова: библейские аллюзии, «усадебный текст», повесть «Аграфена», роман «Дальний край», мотив возвращения блудного сына, мотив несения креста

Об авторе: Михаленко Наталья Владимировна - кандидат филологических наук, старший научный сотрудник Отдела новейшей русской литературы и литературы русского зарубежья, Институт мировой литературы им. А. М. Горького Российской академии наук (121069, Российская Федерация, г. Москва, ул. Поварская, 25a)

Дата поступления: 23.02.2019

Дата публикации: 28.06.2019

Для цитирования: Михаленко Н. В. Библейские аллюзии в усадебном тексте Б. К. Зайцева (повесть «Аграфена» и роман «Дальний край») // Проблемы исторической поэтики. - 2019. - Т. 17. — № 2. - С. 272-288. DOI: 10.15393/j9.art.2019.6642

(C) Н. В. Михаленко, 2019 
Б иблейские аллюзии в творчестве Б. К. Зайцева неоднократно рассматривались литературоведами. Однако с этой точки зрения исследовался прежде всего эмигрантский период творчества писателя. Религиозная проблематика ранних, доэмигрантских, произведений Зайцева (напр., повести «Аграфена» (1908) и романа «Дальний край» (1912)) в работах Е. Ф. Дудиной, Н. А. Ивановой, О. Г. Князевой и других ученых была рассмотрена фрагментарно.

В этих произведениях Зайцева библейскими аллюзиями, мотивами маркируется «усадебный текст»1. Наряду с отразившимся в текстах «пантеизмом», отголоском влияния на мировоззрение Зайцева философии Вл. С. Соловьева ${ }^{2}$, здесь, как отмечал сам писатель, «начинают проступать мотивы религиозные - довольно еще невнятно (“Миф", “Изгнание”) все же в христианском духе. Этот дух еще ясней чувствуется в первом романе “Дальний край” (1912), полном молодой восторженности, некоторого прекраснодушия наивного...» $(4,589)$. Как отмечала О. Г. Князева, еще в доэмигрантских текстах Зайцева был разработан «мотив пути, жизни и смерти в их христианском преломлении» [Князева: 116].

Тема усадьбы гармонично раскрывается в раннем периоде творчества писателя с его «импрессионизмом, молодой “акварельностью”, «тургеневско-чеховским оттенком, сквозившим иногда в конце предреволюционной полосы» $(4,591)$. Интересно, что к произведениям И. С. Тургенева, создавшего свой усадебный миф, Зайцев обращался в течение всей жизни и написал о нем около двадцати очерков, статей, заметок, создал беллетризованную биографию писателя. Как отмечал B. М. Толмачев, «судьба уготовила Зайцеву пройти во многом тургеневскими путями: он ощутил благословение тех же мценских мест, тех же зим в усадьбе, той же хлебосольной Москвы...» [Толмачев: 517] (см. об этом: [Куделько]).

Орловско-Тульско-Калужский край Б. К. Зайцев называл «Тосканою русской» ${ }^{3}$. Значительную роль в творчестве писателя сыграла усадьба его отца в селе Притыкино Каширского уезда Тульской губернии. В Притыкине Зайцев создал цикл рассказов «Аграфена» (1907), «Спокойствие» (1909), «Студент Бенедиктов» (1913), «Грех» (1914), «Изгнание» (1914), «Мать 
и Катя» (1915), «Маша» (1916) и повесть «Голубая звезда» (19161918). Каждое лето Борис Зайцев с двоюродными сестрами Надей и Верой отдыхал в имении матери Будаки в десяти верстах от Калуги ${ }^{4}$. Здесь зародился его интерес к Космосу, началось увлечение астрономией, звездным небом. Характерно, что и герои его ранних повести "Аграфена» и романа «Дальний край», находясь в усадьбе, постоянно вглядываются в небо, которое служит как бы мерилом жизненной правды. В романе «Заря» (1937), первой части автобиографической тетралогии «Путешествие Глеба», созданной в эмиграции, отразились воспоминания Б. Зайцева об этом поместье:

«Все казалось необыкновенным: белоствольные рощи березовые, тесно окружающие усадьбу <...>, небольшой дом, насквозь проникнутый запахом странным - его источали и стены, и старинная мебель <...>. Тропинкою вдоль частокола повернуть вправо, $<\ldots>$ в теплом, райски-благословенном благоухании сада дойти до калитки в частоколе - отворить ее, выйти. <..> И вот пред тобой Божий мир! Вот он, тут! <...> казалось тогда, что нагорный их берег высок, горизонт за Окою огромен, что эти поля, рощи, имение Авчурино наискосок за рекой, белеющий в парке дом все это прекрасно и необычайно» $(4,71-72)$.

Как писала Н. А. Иванова, «с 1910-х годов семантика библейского кода становится доминирующей в характеристике художественного мира произведений Б. Зайцева» [Иванова: 91]. Она отмечала, что «библейский код проявляется многоаспектно: через код странствия, код греха и код веры» [Иванова: 92]. В усадебном тексте, связанном в повести «Аграфена» с образом крестьянской жизни и в романе «Дальний край» с картинами помещичьего быта, раскрываются близкие библейские мотивы, аллюзии, символы ${ }^{5}$ Это мотив возвращения блудного сына, обращающегося к своим истокам, мотив преемственности поколений и сохранения памяти, странничества по земле с целью постигнуть самого себя и бога, мотив пути, следования своей звезде. Через осознание природы как храма раскрывается образ сада души, который человек должен возделывать. Пройдя сквозь испытания, свои страсти, герои этих текстов приходят к христианскому мировоззрению, смиренному принятию своей судьбы. В «Дальнем крае» раскрываются аллюзии 
к образу апостола Петра как столпа новой веры - происходит осознание своих возможностей, своего пути Петей Лапиным, в повести «Аграфена» героиня принимает чашу скорбей, жизни.

Усадьба в повести «Аграфена» является своеобразной точкой отсчета в жизни героини, местом, куда она приходит после искушений и испытаний. Жизнь в усадьбе становится частью ее своеобразного служения. После работы в городе, получив отпущение грехов, героиня возвращается к дочери, принимает свою судьбу, укрепившись в вере.

Своеобразным духовным камертоном в повести служит образ неба и облаков, глядя на которые в усадьбе, герои задумываются о своей жизни. Он становится символом возвращения к истокам, мечты о прекрасном прошлом, поре детства и невинности. Молодой барин грустит:

«- Отчего так бывает, смотришь на небо и облачка такие, кажется, когда-то в детстве видел это, - а когда, не помнишь. И как тогда чудесно было... Вот и лето, и все, а тогда было другое.

Груше с этими словами показалось, что опять он не веселый и смеющийся, а тайный, далекий - такой, как когда читает книги или смотрит подолгу вдаль» $(1,94)$.

Такие переживания героя близки тоске об утраченном рае, поре невинности. Когда Груша думает о расставании с возлюбленным, появляется близкая картина - облака как бы становятся символом мечты о недостижимом счастье:

«...то глядела на загадочные облака над солнцем угасающим, и думала, что так же растает и он, так же золотой, недосягаемочудесный» $(1,95)$.

Образ глубокого неба является в повести маркером жизни в согласии с природой, служит отправной точкой в раздумьях героя о существовании божественного промысла:

«Незаметно наступил тот короткий предвечерний час, когда золотее все, умиреннее, и в зеркальной глубине светлого неба как бы чуешь правду чистую и бесконечную» $(1,93)$. 
Возвращение Аграфены в родную деревню также маркируется появлением образа неба, восприятием героиней природы как родной обители. Здесь завуалирован мотив возвращения блудного сына и евангельский призыв быть «как дети» (Мф. 18:3) - обрести чистоту души:

«Так брела Аграфена, широко ступая ногами в лаптях, упираясь рукой в длинный посох. И ее душа была раскрыта, детскими глазами глядело в нее вечно синеющее небо, и ветерок-ласкатель звенел в ушах, опьянял» $(1,109)$.

Размышления героини над смыслом смерти, принятие ею конца своей жизни также связаны с образом неба, величия и красоты природы:

«Иногда выходила на мороз, и зрелище синих, пылающих светил и глубокой порфиры неба, священных костров созвездий говорило о великом и ангелическом. Чувство твердости, вечности наполняло ее» $(1,112)$.

По мысли А. А. Дриняевой, герои Зайцева «не боятся ухода, но и не сопротивляются ему, ничего не делают, чтобы продлить свои земные часы» [Дриняева: 123].

В повести образ главной героини адресует читателя к житию святой Агриппины Римской. В диссертации М. Л. Вилесовой отмечалось, что повесть близка к житийному канону «хронотопически (изображен длительный отрезок жизни героини) и концептуально (в финале представлено духовное преображение героя)» [Вилесова: 47]. В народном сознании образ христианской святой был близок к языческой Аграфене Купальнице, сопрягался с традиционными купальскими обрядами, природными циклами. Любовь крестьянки Аграфены к молодому барину связана в тексте с картинами летнего расцвета природы:

«Краснел май, пролетая в огненных зорях, росах; кукушки медово куковали, точно окуковывали молодую жизнь. Солнце вставало пламенным и пахучим, глубокими ароматами дымились луга под ним, и скаты розовели, окровавившись “зарей”, медвяно-липкой пурпурной травкой» $(1,93)$. 
Образ Аграфены связан как с языческой, так и с христианской символикой. Она возносит свои молитвы и Богородице, и всему природному миру:

«В последний вечер обняла она его <барина> колени и не могла оторваться. После он уплыл в вечернюю мглу, а она стала на коленях и молилась вслух полям, овсам, небу, Богоматери кроткой и милостивой, посетившей в тот вечер нивы» $(1,95)$.

В этом женском образе соединены как стихийное следование своим желаниям и порывам, так и христианское принятие всех своих скорбей и страданий.

Для ранних текстов Зайцева характерно цикличное время, обращающее читателя к природному кругу повторяющегося рождения и умирания («Так идет в полях, отражая вечные образы любви, любовь дочери - там почти, где много лет назад, загадочно и обольстительно любила мать» - 1, 114), обусловленное также и богослужебным кругом - вечным повторением истории Христа. Герои проходят свои испытания, проживают свои страсти, обретая веру.

В «Аграфене» и «Дальнем крае» возвращение в усадьбу знаменует определенный этап духовного развития героев. В этой связи важно отметить, что эпиграфом к первой части романа «Дальний край» выступают слова Христа: «идите и вы в виноградник мой» (Мф. 20:7), - обращающие к притче о том, что все трудившиеся вне зависимости от того, в какой час они пришли, будут вознаграждены. Не случайно Зайцев в письме к поэту, журналисту Е. Л. Янтареву от 16 июля 1911 г. говорил о том, что внутреннее содержание романа заключается в описании «развития личности, перехода от юношества и ребячества к зрелости в человеке»7. Большую роль здесь играет мотив пути, который символически можно истолковать как «созидательную духовную деятельность человека на пути познания Бога, Божьей истины» [Бронская: 53].

В этих произведениях Зайцева раскрывается тема работы на земле и возделывания своего сада. В повести «Аграфена» молодой барин, плохо умеющий работать на покосе, трудится вместе с крестьянами (“Господи, надорвется”, - думала, а он, напрягая все тонкое тело, с раскрасневшимися щеками, 
подымал на вилах стопу сена» - 1, 93). В «Дальнем крае» Лизавета, пока Петя изучает философские книги, не пренебрегает простым трудом - уборкой сена.

Рассмотрим подробнее мотив возвращения странника в родную обитель в повести «Аграфена». Если в начале произведения героиня идет «по тропинке богомолок» $(1,91)$, то, возвращаясь в усадьбу, сама обретает черты странницы:

«Она купила на базаре вдовий платочек, надела зипун, как богомолки, палку выломила толстую, и боковой тропкой большака, священным путем странников, меряющих родимые пустыни, тронулась в путь» $(1,108)$.

Жизнь в деревне, забота о дочери, возвращение к истокам, на свою землю помогает героине прийти к глубоко христианскому мировоззрению и смиренно принять свою долю, увидеть в судьбе Божественный промысел, со смирением переосмыслить жизненный путь:

«...вся жизнь взглянула в ответ оттуда, чуть заволокнутая легкой слезой, но также обожествленная и просиянная. Ее дни, скорби, утраты, та печаль расставания, что глодала ее сейчас, на мгновение были приняты в светлое лоно. И там преобразились» $(1,111)$.

Вероятно, такое внутреннее преображение мотивировано принятием Аграфеной Заповедей блаженства Христа («Блаженны нищие духом, ибо их есть Царство Небесное. Блаженны плачущие, ибо они утешатся. Блаженны кроткие, ибо они наследуют землю» - Мф. 5:3-5). Героиня не ропщет на судьбу, не осуждает других людей, она тверда в своем смирении, что помогает ей осознать свою жизнь как путь испытаний, посланных Богом, почувствовать Божью милость:

«Тогда она пала на колени, и внутреннее видение осенило ей душу; вся жизнь явилась ей в одном мгновении; все любви и муки понялись одинокими ручьями, сразу впавшими в безмерный и божественный океан любви, и данными ей как таинственные прообразы Любви единой и вечной» $(1,116)$.

Интересно, что в работе «Жизненная драма Платона» Вл. Соловьев ${ }^{8}$ сравнивал Заповеди блаженства с парадоксами Сократа, а ранний период творчества Зайцева сопряжен с чтением 
трудов русского философа, о чем он писал в автобиографическом очерке «О себе» $(4,588)$ (см. подробнее: [Локтионова]).

После смерти дочери Аграфена предстает в своей молитве как «скудельный сосуд» $(1,98)$. Зайцев использует образ глиняного (скудельного) сосуда из Второго послания апостола Павла коринфянам, чтобы подчеркнуть основанное на глубокой вере смирение героини повести, осознающей и принимающей, что «безбрежная река» жизни «в своем безмерном ходе не знает ни границ, ни времени, ни жалости, ни любви; ни даже, как казалось иногда, вообще какого-нибудь смысла» $(1,113)$. Ее безропотность в принятии скорбей соотносима со словами апостола Павла: «Мы отовсюду притесняемы, но не стеснены; мы в отчаянных обстоятельствах, но не отчаиваемся; мы гонимы, но не оставлены; низлагаемы, но не погибаем»; «Посему мы не унываем; но если внешний наш человек и тлеет, то внутренний со дня на день обновляется» (2 Кор. 4:89, 16). Праведность Аграфены проявляется именно в открытости ее сердца Божественному откровению (видение черной монашенки), отсутствии роптания на Бога.

В романе Зайцева «Дальний край» усадьба выступает местом, где герои подводят некоторые итоги после жизни в городе, его суеты и волнений. Важнейшие моменты осмысления своей судьбы и дальнейшего пути проходят именно здесь. После свадьбы Петя и Лизавета живут в усадьбе. Петя старается здесь "решить вопросы, все настоятельнее встававшие в его уме» $(1,492)$, осмыслить философские концепции Вл. Соловьева и И. Канта, понять направление собственной жизни. В этом эпизоде обнаруживаются автобиографические черты. В заметке «О себе» Зайцев отмечал:

«Соловьевым зачитывался я в русской деревне, в имении моего отца, короткими летними ночами. И случалось, косари на утренней заре шли на покос, а я тушил лампу над “Чтениями о Богочеловечестве”. Соловьев первый пробивал пантеистическое одеяние моей юности и давал толчок к вере» $(4,588)$.

Постигая красоту деревенского пейзажа, Петя осознает разницу между мировоззренческими теориями и реальностью жизни, начинает лучше понимать себя и основы своей веры: 
«...у него являлось чувство глубокой его и своей правоты, когда вечером он сидел в поле на копне клевера, в лучах солнца танцевали мушки, вдали бабы убирали сено. Когда, безмолвные и великие, расстилались русские поля, в убогой деревушке блестело алмазом стекло. Душистым вечером гасло солнце, над скромной страной зажигались звезды. Их язык был отчасти понятен. Все, что они говорили - было за какую-то большую правду, вышечеловеческую, вместить которую целиком не дано ни ему, ни идеалистам из сборника, ни даже самому Соловьеву» $(1,493)$.

В текстах Зайцева образ звезды выступает как «знак возникновения особого, космического измерения бытия, как надежда и трепет, наконец, развивая мысль о завете с Богом, как путеводная звезда» [Воробьева: 48]. Здесь можно провести параллель с образом Вифлеемской звезды, приведшей волхвов к младенцу Христу, ведь и герои Зайцева также ищут свою дорогу в жизни, стремятся определить свою миссию.

Как писала О. Н. Калениченко, именно в усадебном топосе, «четко организованном и защищенном от мелких волнений и неприятностей быта», человек на лоне природы может «возвышаться умом и сердцем до осмысления бытийственных основ человеческой жизни» [Калениченко: 110]. Красота и гармония природы как бы подводят Петю к чувству божественности всего сущего, своеобразному пантеизму:

«На теплом, нежно-персиковом востоке вырезываются ветви ракит. Звезда повисла прозрачной каплей»; «Мир кажется тихим храмом, где присутствует сам Создатель» $(1,493,494)$.

В романе «Дальний край» раскрывается символика неба и звезд. Как и в повести «Аграфена», эти образы, связанные с усадебным топосом, становятся для героев своеобразным мерилом духовности и сопряжены с их осознанием истины, актуализируют мотив возвращения блудного сына. Такие моменты в жизни героев маркирует образ звезд:

«Он вышел из усадьбы в ржаное поле. Кричали перепела. Где-то далеко гремели телеги, брехали собаки. Арктур низко горел над усадьбой. Небо было чисто, ясно, и казалось, что пред его лицом человек не может сказать неправды» $(1,500)$; «Петя взглянул вверх, в небо - в глубину и бездонность, казавшуюся ему Божественным судьей земных дел...» $(1,432)$. 
По мнению Е. Ф. Дудиной, «наедине с лунным и звездным светом герои произведений Б. К. Зайцева чувствуют и постигают истину <...>. Звезда выступает символом вселенской любви и красоты» [Дудина: 185]. И человек начинает чувствовать себя не песчинкой мироздания, а частью этой Божественной любви.

Таким образом, в романе «Дальний край» усадебный сад становится местом познания героями самих себя и мира. Созерцание природы служит для Пети такой же отправной точкой формирования его мировоззрения, как и чтение философских трудов:

«Он сидит над речкой, смотрит на закат, видит ясную воду, небо, березу, - и думает, есть ли эта береза живое существо, младшая сестра его, человека, в бытие которой он верит, как в собственное, - так выходит по Соловьеву, - или химера его мозга» $(1,497)$.

В этой связи можно привести слова Д. С. Лихачева: «Сад это подобие Вселенной, книга, по которой можно “прочесть" Вселенную. Вместе с тем сад - аналог Библии, ибо и сама Вселенная - это как бы материализованная Библия. <...> высшее значение сада - рай, Эдем. Сад можно и должно “читать”, и поэтому главное занятие в саду - чтение книг» [Лихачев: 17].

Не случайно отец первой возлюбленной Пети, Ольги Александровны, говорит, что «сады - это главное <...> сады и леса. Вы думаете, - да, наверно, и ваши революционеры тоже, что лес - это что-то пустое. Нет-с, я вам скажу:-лес основа жизни. Без леса нет природы, а природа - колыбель человека» $(1,418)$.

Мотив странничества, проживания испытаний и страстей в городе и подведение неких жизненных итогов в деревне реализуется в романе "Дальний край». "Аркадская жизнь» зимой в усадьбе становится для Пети временем, когда «душа его раскрывалась свету искусства» $(1,518)$, в этот период складываются его духовные ориентиры. Не случайно он с интересом читает «Легенду о Юлиане Милостивом» Г. Флобера рассказ о католическом святом, покровителе путников. Петя мечтает о поездке в Италию, приобщении к другой культуре, 
открытии новых горизонтов, своеобразном духовном странничестве:

«Он был беден, без всяких ожиданий в будущем, но мир прекрасного, все прочнее овладевая, - звал, манил, и нередко в сумерки, в серой русской деревне, он мечтал об иных небесах, ином свете» $(1,518)$.

Слова о бедности Пети и отсутствии у него каких-либо ожиданий можно истолковать здесь и символически как принятие собственной судьбы, доли, отсутствие необходимости менять жизнь других, общества, борясь за воплощение своих идеалов, как это делал другой герой романа Степан. Можно соотнести авторскую характеристику героя с евангельской заповедью Христа о смирении и принятии своей слабости перед силой Бога - «Блаженны нищие духом, ибо их есть Царство Небесное» (Мф. 5:3).

После смерти дедушки, Алеши, гибели Степана Петя и Лизавета вновь возвращаются в усадьбу, как бы пройдя еще один виток испытаний, искушений, пережив страсти и укрепившись в вере и собственных взаимоотношениях.

Вместо мотива возвращения блудного сына начинает звучать мотив зарождения новой веры, связанный с евангельским образом Петра как оплота, камня новой веры ${ }^{9}-$ появляется образ человека, устойчивого в выборе своего пути:

«Сердце его говорило, что он, Петр Ильич Лапин, еще недавно студентик Петя, будет стоять в рядах людей культуры и света и, насколько дано ему, - проводить в окружающее эти начала. В этом его, как и вообще всякого человека, - назначение» $(1,577)$.

Не случайно именно в этот момент совместной жизни Пети и Лизаветы у них должен появиться ребенок. Интересно, что движение ребенка в утробе матери сравнивается с «плеском рыбки»:

«Кто это будет - новый человек, дающий уже о себе знать легким трепетанием, как плеск рыбки?» $(1,578)$.

Можно провести здесь параллель с ихтисом, древней монограммой имени Иисуса Христа, аллегорически обозначавшейся в виде рыбы. Ребенок тогда выступает знаком того нового, 
что готовы нести в жизнь Петя и Лизавета. Герои, познав себя, преобразившись, готовы стать «ловцами человеков» (Мф. 4:19; Мк. 1:17).

В романе «Дальний край» мифологема камня связана и с образом Степана, сумевшего найти оплот своей веры. В ночь перед казнью Степан

«вынул из кармана камень, тот скромный итальянский кругляк, который проехал с ним тысячи верст, и подумал, что девиз этот: "Dominus det tibi pacem" оказался исполненным: Бог действительно дал мир и твердость его душе» $(1,576)$.

Также эта мифологема раскрывается и в образах Алеши и Ольги Александровны, героев, которые «интонируют в произведении тему Италии, столь важную для Зайцева: именно через восприятие этих героев дается один из ключевых топосов Италии - собор Святого Петра» [Захарова: 73]. После смерти Алеши Ольга Александровна находит утешение именно в величественной картине Рима:

«За Тибром виднелся храм Петра. Слегка шумели платаны на набережной, и в тихом плеске реки, в луне, окаймленной оранжевым кругом, в пустынной римской ночи звучал один великий мотив: вечность» $(1,561)$.

Таким образом, усадьба в повести Зайцева «Аграфена» и романе «Дальний край» становится местом духовной эволюции героев, именно там происходит осознание ими своего пути. Пройдя в своем духовном развитии этап искушений и странничества, герои принимают Заповеди блаженства, евангельский завет Христа быть открытыми сердцем. Библейские аллюзии, особенно мотив возвращения блудного сына в родные места, на землю предков, сакрализируют усадебный топос.

\section{Примечания}

* Исследование выполнено в ИМЛИ РАН за счет гранта Российского научного фонда (проект № 18-18-00129) «Русская усадьба в литературе и культуре: отечественный и зарубежный взгляд».

1 О такой особенности усадебной повести или романа, соотнесенности их сюжетных коллизий с известными литературными и библейскими мотивами («искушения, грехопадения и искупления, ситуациями “потерянного” и “возвращенного” рая») писал В. А. Доманский [Доманский: 58]. 
2 «Соловьев первый пробивал пантеистическое одеяние моей юности и давал толчок к вере», как писал Б. К. Зайцев в своей автобиографии (Зайцев Б. К. О себе // Зайцев Б. К. Собр. соч.: в 5 т. М.: Русская книга, 1999. Т. 4: Путешествие Глеба: Автобиографическая тетралогия. С. 588). Далее ссылки на это издание приводятся в тексте статьи с указанием тома и страницы в круглых скобках.

3 Зайцев Б. К. Собр. соч.: в 5 т. М.: Русская книга, 1999. Т. 5. Жизнь Тургенева: Романы-биографии. Литературные очерки. С. 21.

4 См. об этом подробнее: [Зайцев], [Фридгельм].

5 Как отмечалось в книге Е. Е. Дмитриевой и О. Н. Купцовой, русская помещичья усадьба, с одной стороны, - «пространство культуры, но в естественном, природном ландшафте», с другой - сочетание, «включение в себя равно миров дворянского и крестьянского» [Дмитриева: 16-17].

6 См. также: [Безатосная: 79].

7 Зайцев Б. К. Собр. соч.: в 5 т. М.: Русская книга, 2001. Т. 10 (доп.). Письма 1901-1922 гг. Статьи. Рецензии / сост. Е. К. Дейч и Т. Ф. Прокопов. С. 80.

8 Соловьев В. С. Жизненная драма Платона // Соловьев В. С. Сочинения: в 2 т. М.: Мысль, 1988. Т. 2. С. 582-625.

9 «Я говорю тебе: ты - Петр, и на сем камне Я создам Церковь Мою, и врата ада не одолеют ее; и дам тебе ключи Царства Небесного: и что свяжешь на земле, то будет связано на небесах, и что разрешишь на земле, то будет разрешено на небесах» (Мф. 16:18-19). См.: Мейендорф И. Ф. Апостол Петр и его преемство в византийском богословии // Православная мысль. - 1957. — № 11. - С. 139-157.

\section{Список литературы}

1. Безатосная О. М. Православные идеи в рассказе Б. Зайцева «Аграфена» как отражение культурной картины мира // Актуальные вопросы современной филологии и журналистики. — 2006. — № 1 (1). - С. 79-82.

2. Бронская Л. И. Русская идея в автобиографической прозе русского зарубежья: И. С. Шмелев, Б. К. Зайцев, М. А. Осоргин. - Ставрополь: Изд-во СГУ, 2000. - 100 с.

3. Вилесова М. И. Семантика женских образов в прозе Б. К. Зайцева: дис. ... канд. филол. наук. - Томск, 2016. - 191 с.

4. Воробьева Г. В. Идейно-художественное своеобразие малой прозы Б. К. Зайцева. - Волгоград: ИУНЛ ВолгГТУ, 2011. - 175 с.

5. Дмитриева Е. Е., Купцова О. Н. Жизнь усадебного мифа: утраченный и обретенный рай. - М.: ОГИ, 2003. - 528 с.

6. Доманский В. А. Русская усадьба в художественной литературе XIX века: культурологические аспекты изучения поэтики // Филологические науки. - 2005. - С. 56-60.

7. Дриняева А. А. Особенности ранней малой прозы Б. К. Зайцева // Калужские писатели на рубеже Золотого и Серебряного веков: сб. ст. 
Пятые Международные юбилейные научные чтения. - Калуга: Институт повышения квалификации работников образования, 2005. Вып. 5. - С. 122-125.

8. Дудина Е. Ф. Своеобразие художественного метода Б. К. Зайцева 1900-1921 годов // Ученые записки ОГУ. Серия: Гуманитарные и социальные науки. - 2012. - № 5. - С. 183-188.

9. Зайцев Е. Н. Дворянская усадьба в жизни Бориса Зайцева // Зайцев Е. Н. Русский писатель земли Калужской. - Калуга: Фридгельм, 2004. - C. 66-72.

10. Захарова В. Т. Поэтика прозы Б. К. Зайцева. - Н. Новгород: Мининский университет, 2014. - $166 \mathrm{c}$.

11. Иванова Н. А. Художественный мир произведений Б. К. Зайцева 1900-1922-х годов в аспекте кодовых взаимодействий: дис. ... канд. филол. наук. - Чебоксары, 2014. - 188 с.

12. Калениченко О. Н. Мир усадьбы в творчестве Б. К. Зайцева // Международный научно-исследовательский журнал. — 2014. — № 3-1 (22). C. $109-110$.

13. Князева О. Г. Христианская картина мира в творчестве Б. К. Зайцева 1900-1920-х гг. // Калужские писатели на рубеже Золотого и Серебряного веков: сб. ст. Пятые Международные юбилейные научные чтения. - Калуга: Институт повышения квалификации работников образования, 2005. - Вып. 5. - С. 116-122.

14. Куделько Н. А. И. С. Тургенев и русская литература XX в. (Б. Зайцев, К. Паустовский, Ю. Казаков). - Орел: ОГИИК, 2001. - 189 с.

15. Лихачев Д. С. Поэзия садов: к семантике садово-парковых стилей. 2-е изд., испр. и доп. - Л.: Наука, 1982. - 341 с.

16. Локтионова Е. В. Влияние Вл. Соловьева на мировоззрение и творчество Б. К. Зайцева // Вестник ОГУ. - 2008. — № 9. - С. 16-20.

17. Толмачев В. М. Борис Зайцев // Русская литература 1920-1930-х годов. Портреты прозаиков: в 3 т. - М.: ИМЛИ РАН, 2016. - Т. 1. - Кн. 1. C. $483-548$.

18. Фридгельм В. Н. Село Усты Калужской губернии - малая родина Б. К. Зайцева // Жизнь и творчество Бориса Зайцева: материалы Шестой Международной научно-практической конференции, посвященной жизни и творчеству Б. К. Зайцева. - Калуга: КГИМО, 2011. - Вып. 6. - С. 135-140. 
Natalia V. Mikhalenko

(Moscow, Russian Federation) rinsan-tin@rambler.ru

\section{Allusions to the Bible in the "Estate Text" of Boris Zaytsev (Based upon His Short Story "Agrafena" and the Novel "The Distant Land")}

Acknowledgments. The reported study was performed in the A. M. Gorky Institute of World Literature of the Russian academy of sciences and funded by Russian Science Foundation according to the research project no. 18-1800129 "Russian Estate in Literature and Culture: Domestic and Foreign View". Abstract. The biblical themes and motifs found in the early works of Boris Zaytsev have not been completely studied by the literary scholars. Different researchers (E. F. Dudina, N. A. Ivanova, O. G. Knyazeva and others) analyzed the presence of the New Testament motifs in the story "Agrafena" and the novel "The Distant Land", but did not relate them to the context of a country estate through which they were conveyed. That makes the study of these works a priority from the Christian point of view. This article studies these two works: a novel and a short story - and demonstrates the presence of the motif of returning to an estate after an ordeal, or suffering, or delusion, which is shown like the return of the prodigal son to the father's house; the motif of gaining the faith conveyed as the opportunity to hear and understand oneself, to get into harmony with nature after returning home; the motif of humility, acceptance of the fate, bearing one's cross. Orthodox symbolism (the chalice of sorrows, the stormy sea of life, a stone as the foundation for a new faith) is seem as an important sign for the characters on their way, indicating the right choice, helping them to realize their mission. The motif of a miracle seeing, a dream in "Agrafena", taken by the main character as a divine revelation, is of great importance. In these texts, the country estate becomes a topos the spiritual evolution of characters is closely related to.

Keywords: allusions to the Bible, "estate text", short story "Agrafena", novel "The Distant Land", motif of bearing one's cross, motif of the return of the prodigal son

About the author: Mikhalenko Natalia V. — PhD in Philology, Senior Researcher of the Department of Modern Russian Literature and Russian Literature Abroad, A. M. Gorky Institute of World Literature of the Russian Academy of Sciences (ul. Povarskaya 25a, Moscow, 121069, Russian Federation)

Received: February 23, 2019

Date of publication: June 28, 2019

For citation: Mikhalenko N. V. Allusions to the Bible in the "Estate Text" of Boris Zaytsev (Based upon His Short Story "Agrafena" and the Novel "The Distant Land"). In: Problemy istoricheskoy poetiki [The Problems of Historical Poetics], 2019, vol. 17, no. 2, pp. 272-288. DOI: 10.15393/j9.art.2019.6642 (In Russ.) 


\section{References}

1. Bezatosnaya O. M. Orthodox Ideas in the Story by B. Zaytsev "Agrafena" as a Reflexion of the Cultural Picture of the World. In: Aktual'nye voprosy sovremennoy filologii i zhurnalistiki [Actual Issues of Modern Philology and Journalism], 2006, no. 1 (1), pp. 79-82. (In Russ.)

2. Bronskaya L. I. Russkaya ideya $v$ avtobiograficheskoy proze russkogo zarubezh'ya: I. S. Shmelev, B. K. Zaytsev, M. A. Osorgin [The Russian Idea in the Autobiographical Prose of the Russian Expatriate Community: Ivan Shmelyov, Boris Zaytsev, Mikhail Osorgin]. Stavropol, Stavropol State University Publ., 2000. 100 p. (In Russ.)

3. Vilesova M. I. Semantika zhenskikh obrazov v proze B. K. Zaytseva: dis. ... kand. filol. nauk [The Semantics of Female Images in B. K. Zaytsev's Prose. PhD. philol. sci. diss.]. Tomsk, 2016. 191 p. (In Russ.)

4. Vorob'eva G. V. Ideyno-khudozhestvennoe svoeobrazie maloy prozy B. K. Zaytseva [The Ideological and Artistic Originality of the Small Prose by B. K. Zaytsev]. Volgograd, Publishing house of educational and scientific literature of Volgograd State Technical University Publ., 2011. 175 p. (In Russ.)

5. Dmitrieva E. E., Kuptsova O. N. Zhizn' usadebnogo mifa: utrachennyy $i$ obretennyy ray [Life of the Estate Myth: Lost and Found Paradise]. Moscow, Ob"edinennoe Gumanitarnoe izdatel'stvo Publ., 2003. 528 p. (In Russ.)

6. Domanskiy V. A. A Russian Country Estate in the 19th Century Fiction: Cultural Aspects of the Study of Its Poetics. In: Filologicheskie nauki [Philological Sciences], 2005, pp. 56-60. (In Russ.)

7. Drinyaeva A. A. The Features of the Early Small Prose by B. K. Zaytsev. In: Kaluzhskie pisateli na rubezhe Zolotogo i Serebryanogo vekov. Pyatye Mezhdunarodnye yubileynye nauchnye chteniya [Kaluga Writers at the Turn of the Golden and Silver Ages. The Fifth International Scientific Readings]. Kaluga, Institute of Improvement of Professional Skill of Educators Publ., 2005, issue 5, pp. 122-125. (In Russ.)

8. Dudina E. F. The Specific Feature of the Method B. K. Zaytsev 1900-1921 Years. In: Uchenye zapiski Orlovskogo Gosudarstvennogo Universiteta. Seriya: Gumanitarnye i sotsial'nye nauki [Scientific Notes of Orel State University. Series: Humanities and Social Sciences]. Orel, 2012, no. 5, pp. 183-188. (In Russ.)

9. Zaytsev E. N. A Noble Estate in Life of Boris Zaytsev. In: Zaytsev E. N. Russkiy pisatel' zemli Kaluzhskoy [Zaytsev E. N. A Russian Writer of the Land of Kaluga]. Kaluga, Fridgel'm Publ., 2004, pp. 66-72. (In Russ.)

10. Zakharova V. T. Poetika prozy B. K. Zaytseva [The Poetics of Boris Zaytsev's Prose]. Nizhny Novgorod, Kozma Minin Nizhny Novgorod State Pedagogical University Publ., 2014. 166 p. (In Russ.)

11. Ivanova N. A. Khudozhestvennyy mir proizvedeniy B. K. Zaytseva 1900-1922kh godov $v$ aspekte kodovykh vzaimodeystviy: dis. ... kand. filol. nauk [The Artistic World of Boris Zaytsev's Works of the 1900s-1922s in the Aspect of Interaction of Codes. PhD. philol. sci. diss.]. Cheboksary, 2014. 188 p. (In Russ.) 
12. Kalenichenko O. N. The World of the Estate in Boris Zaytsev's Works. In: Mezhdunarodnyy nauchno-issledovatel'skiy zhurnal [International Research Journal], 2014, no. 3-1 (22), pp. 109-110. (In Russ.)

13. Knyazeva O. G. A Christian Worldview in the Works of Boris Zaytsev of the 1900s-1920s. In: Kaluzhskie pisateli na rubezhe Zolotogo i Serebryanogo vekov. Pyatye Mezhdunarodnye yubileynye nauchnye chteniya [Kaluga Writers at the Turn of the Golden and Silver Ages. The Fifth International Scientific Readings]. Kaluga, Institute of Improvement of Professional Skill of Educators Publ., 2005, issue 5, pp. 116-122. (In Russ.)

14. Kudel'ko N. A. I. S. Turgenev i russkaya literatura XX v. (B. Zaytsev, K. Paustovskiy, Yu. Kazakov) [I. S. Turgenev and Russian Literature of the 20th Century (B. Zaytsev, K. Paustovsky, Yu. Kazakov)]. Orel, The Orel State Institute of Culture Publ., 2001. 189 p. (In Russ.)

15. Likhachev D. S. Poeziya sadov: $k$ semantike sadovo-parkovykh stiley [The Poetry of Gardens: on the Semantics of Landscape Styles]. Leningrad, Nauka Publ., 1982. 341 p. (In Russ.)

16. Loktionova E. V. The Influence of Vl. Solovyov on the Worldview and Works of B. K. Zaytsev. In: Vestnik Orlovskogo gosudarstvennogo universiteta [Bulletin of Orel State University], 2008, no. 9, pp. 16-20. (In Russ.)

17. Tolmachev V. M. Boris Zaytsev. In: Russkaya literatura 1920-1930-kh godov. Portrety prozaikov: $v 3$ tomakh [Russian Literature of the 1920s-1930s. Portraits of Writers: in 3 Vols]. Moscow, the Gorky Institute of World Literature of the Russian Academy of Sciences Publ., 2016, pp. 483-548. (In Russ.)

18. Fridgel'm V. N. The Village of Usta of Kaluga Province is the Small Motherland of B. K. Zaytsev. In: Zhizn' i tvorchestvo Borisa Zaytseva: materialy Shestoy Mezhdunarodnoy nauchno-prakticheskoy konferentsii, posvyashchennoy zhizni i tvorchestvu B. K. Zaytseva [The Life and Works of Boris Zaytsev: Proceedings of the Sixth International Scientific and Practical Conference Dedicated to the Life and Work of B. K. Zaytsev]. Kaluga, Kaluga State Institute of Education Development Publ., 2011, issue 6, pp. 135-140. (In Russ.) 